\title{
連成解析の設計段階における適用事例：床吹出し空調方式導入時 $\mathrm{CFD}$ と連成した空調システムシミュレーションに関する研究 第 1 報
}

\section{CASE STUDY IN DESIGN PHASE FOR AIR CONDITIONING USING UNDER-FLOOR \\ Study on energy simulation coupling with CFD for HVAC system Part 1}

\section{尹 奎 英*1 $^{*}$, 近藤順也 ${ }^{* 2}$, 坂井友香*2, 竹島卓磨*3 飯塚 悟*4, 渡辺 剛*5, 奥宮正哉*6 \\ Gyuyoung YOON, Junya KONDO, Yuka SAKAI, Takuma TAKESHIMA, Satoru IIZUKA, Takeshi WATANABE and Masaya OKUMIYA}

\begin{abstract}
The subject of this study is to improve the efficiency of the air-conditioning system, and to support the life cycle energy management for HVAC system of the building. And, it is considered that the HVAC system simulation tool coupling with CFD is a useful measure to realize the subject of this study.

In this paper, it is described the significance to apply the coupling HVAC simulation tool and CFD. And, the application possibility in each phase of the life cycle energy management is shown. Also, the case study result corresponding to HVAC system using under-floor will be shown at the design stage. The cooling load of chilled water was estimated by applying system simulation tool with coupling with CFD. We found out that it is possible to estimate the proper cooling load of chilled water while the distribution of room temperature is represented by CFD. Finally, the energy consumption and system COP for primary sub-system with cooling load of chilled water estimated by using the couple with CFD.
\end{abstract}

Keywords : HVAC System, Coupling with CFD, Cooling Load of Chilled Water, Design Phase 空調システム, CFD 連成, 装置負荷, 設計段階

\section{1. はじめに}

建築空調分野での設計は、建物の最大空調負荷に耐えうるシステ ムの設計に重点を置いてきた。しかし、建物に要求される負荷は、 運用時の大半において、最大負荷の半分にも満たない低負荷が占め る。一方で、空調設備・機器のその運転性能特性はまちまちではあ るが、低負荷運転時に効率の低下が現れ、部分負荷運転時にシステ ムの運転効率低下を招くことが指摘されている。そこで、空調シス テムシミュレーションは、システムの部分負荷効率を考慮した期間 性能評価を可能にし、システムの設計、施工、運用の適切化を図る 手段として期待される。

空調システムの熱負荷計算は然ることながら既往のシステムシミ ュレーションの殆どでは、瞬時一様拡散の室内環境を仮定しており、 実際の部屋とは異なる室内環境に対して、シミュレーションを行っ ていることになる。また、居住域空調方式のように二次側の環境制 御対象域を局所化し空調効率向上を図るシステムを設計する場合に
は、この差が顕著になる。例え、居住域と非居住域とで空間を分割 して室内環境を考慮するにしても、各空間の環境を瞬時一様拡散と して仮定するのであれば、実際とは異なる空調機器、熱源システム の運転挙動、そしてエネルギー消費をシミュレートすることになる。 この相違を解消し、より現実に充実なシステムシミュレーションを 行うためには CFD と連成することが有効な手段の一つとなる。

そこで本研究は、空調システムのライフサイクルを通してのエネ ルギーマネージメントを支援することを目的とし、CFD を連成する システムシミュレーションの活用を提案するものである。CFD を用 いて室内温度・気流分布性状を再現すると同時に、これを反映した システムシミュレーションを行うことで、システムの挙動を適切に 捉えシミュレーションの精度を高めることを目指す。また、システ ムの設計、施工、運用に際して CFD を連成するシステムシミュレ ーションの有効性と活用方法を提示することを最終目標とする。

CFD の結果をシステムシミュレーション(以下、SysSim と記す
*1 名古屋市立大学芸術工学研究科 准教授 $\cdot$ 博士 (工学)

*2 名古屋大学環境学研究科 博士前期課程

*3 清水建設侏) 修士(環境学)

*4 名古屋大学環境学研究科 准教授・博士 (工学)

*5 NTT ファシリティーズ研究開発本部 主任研究員・修士(工学)

*6 名古屋大学環境学研究科 教授・工博
Assoc. Prof., Graduate School of Design \& Architecture, Nagoya City Univ., Dr. Eng. Graduate Student, Graduate School of Environmental Studies, Nagoya Univ. SHIMIZU CORPORATION, M. Env.

Assoc. Prof., Graduate School of Environmental Studies, Nagoya Univ., Dr. Eng. Senior Research Engineer, NTT Facilities, INC., Research and Development Headquarters, M. Eng.

Prof., Graduate School of Environmental Studies, Nagoya Univ., Dr. Eng. 
る）に活用する発想は以前からあり、Lam らは体育館の換気・空調 システムの最適化のために CFD を用いて居室内の温度分布を計算 し SysSim に用いた 1)。Zhai らは CFD と連成する SysSim の精度 検証、連成方法の提案、感度解析を行った 2)344)。鄭らは体育館の換 気システムの設計において、CFD との連成計算を用いた 5)。飯田ら は空調システムの制御や診断において、CFD と連成計算の有効利用 の可能性を示した ${ }^{6}$ 。

本報では、建物のライフサイクルエネルギーマネージメントの観 点から、CFD を連成する SysSim の適用可能性を考察する。また、 床吹出し空調方式の設計時を想定したケーススタディーを行う。ケ ーススタディーでは、空調システムの装置容量選定に係わるコイル 処理熱量を算出し比較検討することによって、CFD を連成した SysSim の有効性を示す。さらに、コイル処理熱量の予測誤差が及 ぼすエネルギー消費量への影響を検討する。

\section{CFD と連成する SysSim}

\section{1 CFD と連成する SysSim の適用可能性}

$\mathrm{CFD}$ と連成する SysSim の有効な活用方法を図 1 に示す。設計段 階では、最大負荷時のみならず、部分負荷時に実現される温熱環境 を的確に予測し、なおその時の装置負荷を推定するなどの設計支援 に活用できると考えられる。

施工・試運転段階では、システムの調整・チューニング時の支援 に活用できると考えられる。また、運用段階では、温熱環境とシス テムの挙動を再現し、システムの制御・監視支援に活用することが 考えられる。

\section{2 SysSim と CFD の連成方法の概要}

図 2 にCFD と SysSim を連成する際、想定しうる 2 つ連成境 界を示す。図に示すとおり、連成境界を空気系統とする場合（その 1）と水系統とする場合（その 2) との 2 つが想定できる。連成境界 その 1 は、空調機の給気、還気の空気温度・湿度、風量が CFD と SysSim の境界条件となる連成方法であり、本研究で採用している 方法である。連成境界その 2 は、泠・温水コイルの往還温度と流量 を境界条件とする連成方法である。この方法は泠水コイルの計算に おいてコイルの熱容量や時間遅れを考虑する動的計算の場合に有効 な方法と考えられる。この 2 つの連成境界は、SysSim ツールが取 り扱える境界条件やコイル計算のやり方により使い分けるとよい。

図 3 に空調 SysSim と CFD の連成周期を示す。ここでは、本報 で行った連成計算の例を示し解説する。初期值の給気温度（図中の (1)）を受け渡し CFD 計算を行う（図中の(2) 一(3)。そして次の時間 の還気温度（図中の(3)）をSysSim 一受け渡し、次の時間の給気温 度（図中の(4)）を計算する。これが単位連成周期となる。1 回目以 後の連成計算では、初期値の給気温度はSysSim からの給気温度に 代わり、受け渡される。殆どは、ステップ応答による一定時間ステ ップ (典型的に 1 時間) 内で収束する前提条件下で行われている。 このことを勘案すれば、図に示す単位連成周期は 1 時間に 1 回とす ることが適切と考えられる。(図中の $\Delta \mathrm{t}$ は 1 時間となる) また、 SysSim 側が動的計算に対応している、あるいは動的要素を無視で きる条件である場合、 1 時間に複数回連成を行い、解を求めること も可能と考えられる。

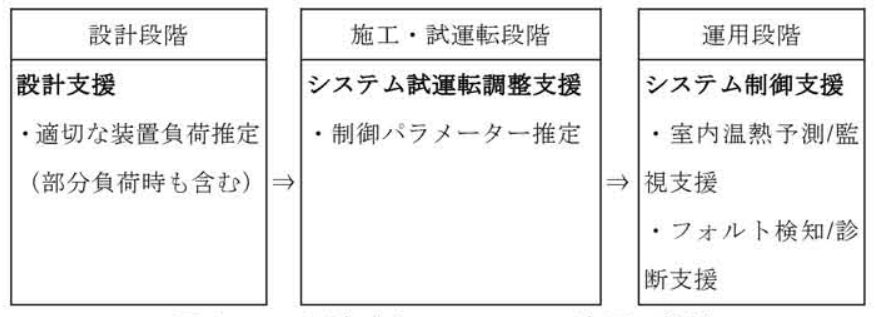

図 1 CFD と連成するSysSim の適用可能性

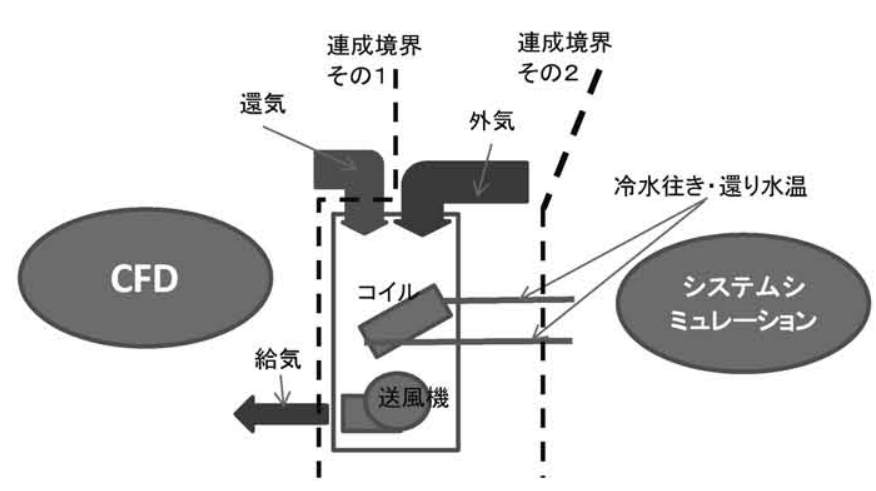

図 $2 \mathrm{CFD}$ との連成境界

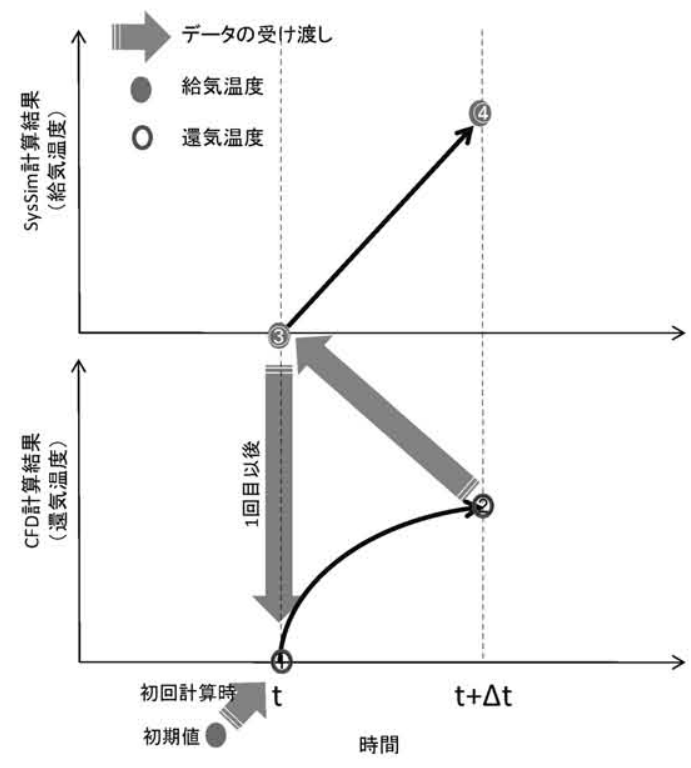

図 $3 \mathrm{CFD}$ との連成周期

本研究では、SysSim は LCEM ッール Ver3.02 を用い、CFD 解 析にはSTREAM Ver.8 を用いる。LCEM ッールは国土交通省大臣 官房官庁営繕部監修のもと開発し普及されつつある空調システムの ライフサイクルエネルギーマネージメントツールであり、既往の文 献 7によりその精度は十分確認されている。STREAM Ver8 は CFD の汎用ツールの一つである。

\section{SysSim と CFD の条件設定 \\ 3.1 検討概要}

本検討では、想定のモデル建物を対象に空調システムの設計を実 施し空調システム全体の SysSim を行う。また、表 1 に示す 3 つの ケースを想定し、これに従い各ケースの装置負荷を算出し比較検討 
する。これにより CFD 連成計算の有無の違いと有効性を検証する。 表 1 に示すケース 0 は天井吹き出しの全域空調方式を採用するケ ースで、瞬時一様拡散の部屋モデルを用いる。ケース 1 とケース 2 は床吹出し空調方式を採用したケースである。また、ケース 1 は部 屋モデルを居住域と非居住域の二層に分割して室内温度分布を考慮 (各層内は瞬時一様拡散すると仮定) したケースである。このケー スは、CFD との連成計算なしのケースであり、設計の実務において 設計者が行い得る比較的容易な手法として位置付けている注1)。これ に対して、ケース 2 は連成計算を行うケースであり、CFD を活用し て室内温度分布を考慮する部屋モデルを採用する。

\section{2 対象建物概要および計算条件}

空調設備設計の対象建物は、東京所在の 9 階建て $\mathrm{RC}$ 造のオフィ スビルを想定した。図 4 に示すように、基準階の空調面積は $1,144 \mathrm{~m}^{2}$ であり、コアを中心に南北に事務空間がある平面プランとした。南 北の各事務空間は 4 つにゾーニング $(\mathrm{N} 1 \sim \mathrm{N} 4 、 \mathrm{~S} 1 \sim \mathrm{S} 4)$ され、南北 それぞれに $2 つ の$ 空調機（北事務室には AC-N1,N2、南側事務室に は AC-S1,S2) を設置した。なお、南北面の空側は、エアフローウ

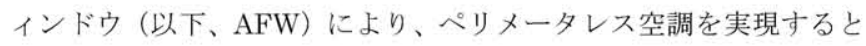
した。また、外壁は断熱条件として本検討の簡便化を図った。

表 2 に対象建物の熱負荷条件を示す。人員密度は 0.1 人 $/ \mathrm{m}^{2}$ とし、 他の条件は一般的なオフィスを想定して設定した。なお、 $\mathrm{AFW} の$ $\mathrm{U}$ 值と $\mathrm{SC}$ 值は $\mathrm{AFW}$ の通過風量と参考文献 ${ }^{8)}$ をもと算定して与 えた。

図 5 にケース 1 と 2 の空調機周りのシステム概念図を示す。空調 吹き出し風量制御は定風量方式を採用する。また、 $\mathrm{AFW}$ への空気 は床下チャンバーより直接取り込み、取り入れ外気量分の空気を常 に流すようにする。ケース 0 は、天井吹き出し方式を採用し、AFW への空気は室内側の空下部から取り込む構造とする。

図 6 に LCEM ッールのモデル構築ダイアグラムを示す。熱源機 器、冷水ポンプ、二次側冷水ヘッダ、コイル、送風機を含む空調機、 そしてダクトと定風量 $(\mathrm{CAV})$ ユニット、室の負荷までを対象とし、 最左側の配管オブジェクトから最右側の室オブジェクトまでを構築 した。

また、図 7 にはケース 2 の検討に用いる CFD の居室モデルを示 す。解析負荷を減らすために、執務空間のうち S3 ゾーン $(11 \mathrm{~m} \times$ $13 \mathrm{~m} \times 2.9 \mathrm{~m} ）$ のみをモデル化した。家具や人体を模擬した直方体ソ リッドを設け、床吹き出し口、還気口を配置した。また、人体と照 明・ OA 機器からの発熱を与えた。表 3 に CFD 解析条件の詳細を示 す。なお、乱流モデルには RNG k- $\varepsilon$ モデルを用いた。RNG k- $\varepsilon$ モ デルはこれまで、様々な乱流場解析に適用され、十分な予測精度を 持つことが検証されている9), 10)。

本検討では、ケース 0、ケース 1 については Micro-HASP/TES for Window を用いて熱負荷を計算する。本検討の目的上、各ケースに 与える熱負荷を同一化して検討を行う必要がある。このためにケー ス 0 とケース 1 の熱負荷計算においては、Micro-HASP/TES for Window の重み係数（内部発熱、壁貫流、日射）を”1”に変更して熱 負荷計算を行った。ケース 2 では CFD 上で内部発熱、熱貫流、日 射熱取得を与えてケース 0 、ケース 1 と同じ負荷条件となるように した。ただし、Micro-HASP/TES for Window では、日射熱取得に

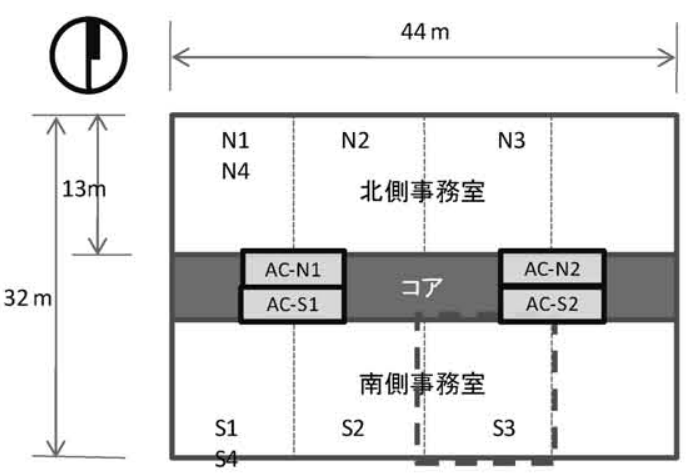

図 4 対象建物の基準階平面図

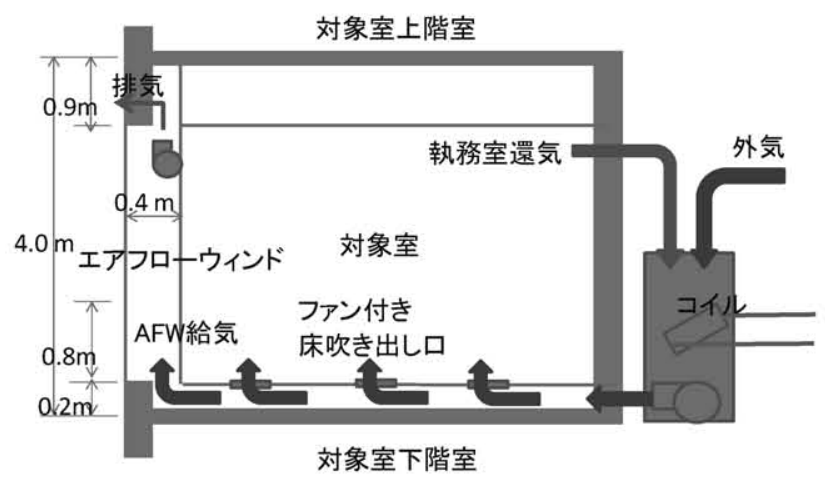

図 5 空調機周りのシステム概念図

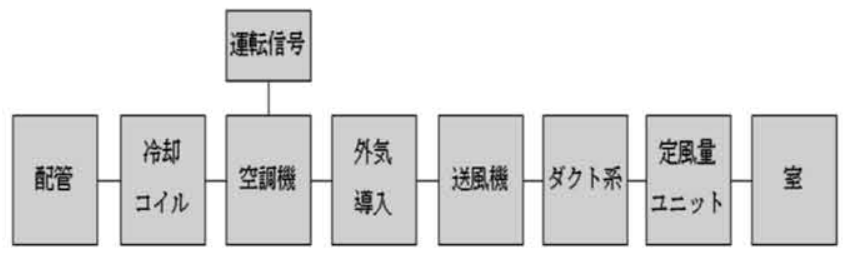

図 6 LCEM ツールのモデルダイアグラム

表 1 検討ケース

\begin{tabular}{|c|c|}
\hline ケース & 意義・位置付け \\
\hline ケース 0 & $\begin{array}{l}\text { ·完全混合と仮定（室内温度分布は考慮せず） } \\
\text { • 天井吹き出しの全域空調方式採用のケース } \\
\text { · CFD との連成計算はしない。 }\end{array}$ \\
\hline ケース 1 & $\begin{array}{l}\text { ·分割層内は完全混合と仮定 (室内温度分布は二層 } \\
\text { 分割で考慮) } \\
\text { ·床吹き出し空調方式採用のケース } \\
\text { · CFD との連成計算はしない。 }\end{array}$ \\
\hline ケース 2 & $\begin{array}{l}\text { - CFD との連成計算を行う。室内温度分布考虑 } \\
\text { • 床吹き出し空調方式採用のケース }\end{array}$ \\
\hline
\end{tabular}

表 2 熱負荷条件

\begin{tabular}{|c|c|c|}
\hline \multicolumn{2}{|l|}{ 人員密度 } & $0.10 人 / \mathrm{m}^{2}$ \\
\hline \multicolumn{2}{|c|}{ 照明（半埋め込みタイプ） } & $20 \mathrm{~W} / \mathrm{m}^{2}$ \\
\hline \multicolumn{2}{|l|}{ コンセント・OA } & $20 \mathrm{~W} / \mathrm{m}^{2}$ \\
\hline \multicolumn{2}{|l|}{ 外気導入 } & $25 \mathrm{~m}^{3} / \mathrm{h}$ 人 \\
\hline \multirow{2}{*}{ 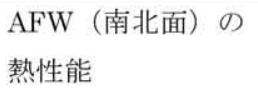 } & $\mathrm{SC}$ 值 & 0.28 \\
\hline & U 值 & $2.08 \mathrm{~W} / \mathrm{m}^{2} \mathrm{~K}$ \\
\hline
\end{tabular}


ついて対流と放射に分けて考虑しているが、CFD では分離せず対流 分として与えた。放射分の割合は対流分に対して非常に小さく、こ の措置による負荷条件の違いは小さいと考えられる。対流分として 与えた熱量は、標準日射熱取得に SC 值を乗じて算出しガラスの室 内側近傍に与えた。照明発熱については、半埋め込みタイプ照明器 具を想定し対流と放射による放熱分を分けて考慮した。天井付近に は照明消費電力の $50 \%$ を対流分と見なして与えた。また、床付近に はその残りを放射分と見なして与えた。

また、ケース 2 の CFD の解析は空調開始時の室温を Micro-HASP /TES for Window の結果から参照するとともに、一日 10 時間の連 続計算を行った。これにより、Micro-HASP/TES for Window で取 り扱う間欠運転による蓄熱負荷を CFD 上で勘案できるように工夫 した。これらの措置をとることよって、Micro-HASP/TES for Window と CFD で考慮する熱負荷条件の同一化を図った。

図 8 に、ケース 2 におけると CFD との連成計算フロー図を示す。 SysSim と CFD の連成は、両者の間で給気と吸い込み(還気)の状態 值(温度・湿度)を授受することで行われる。具体的には、給気温度 ・ 湿度を SysSim 側から CFD 側に受け渡し、CFD 側は受け取った給 気条件で解析を行う。その後、図 7 中に示す室内温度参照点（空調 吹き出し温度制御のためのセンシングポイント) ・ RA 温度参照点に おける状態値を再び LCEM 側へ受け渡す。このやり取りは、図 8 中に示すように 30 秒間隔で行われる。その際、給気温度は比例制 御により決定される。LCEM ッールは 1 時間ステップで静的な計算 を行うッールであるが、ここではコイルの動特性は無いと仮定し 30 秒ステップで計算した。給気温度の上/下限值は $22^{\circ} \mathrm{C} / 14^{\circ} \mathrm{C}$ とし、室 温の比例帯は $24^{\circ} \mathrm{C} \sim 28^{\circ} \mathrm{C}$ とした。

今回の検討では、室内温度参照点を室中央、高さ $1.7 \mathrm{~m}$ の位置に 設置した。この点の位置が変われば、室内環境やSysSim 側の挙動 は当然異なるものと考えられる。従って、参照点の最適な位置につ いては今後更なる検討が必要である。

\section{3 各ケースの空調機仕様決定}

ここでの検討は簡便のために、図 4 の空調機 AC-S2 のみに限定 して装置負荷の算定を行った。各ケースの空調機設計のために、 Micro-HASP/TES for Window を用いて熱負荷計算を行った。熱負 荷計算は全域空調採用時の場合（ケース 0 に対応）と床吹き出し採 用時の場合（ケース 1,2 に対応）の二通りを行った。前者は、従来 の負荷計算方法とおりのものであり、空間内の温度と湿度を完全混 合すると仮定して熱負荷計算を行ったものである。後者は、事務空 間を居住域と非居住域とで二層に分割し、上下の温度分布を簡易的 に考慮して熱負荷計算を行ったものである。また、各層内の上下温 度分布、水平分布については考慮せず、設計者が実務レベルで実行 可能な手法として想定している。後者の床吹き出し空調採用時の熱 負荷計算方法については注 1)を参照されたい。負荷計算は図 4 中の $\mathrm{S} 3$ ゾーンのみを対象に行い、 2 倍して $\mathrm{S} 3$ と $\mathrm{S} 4$ ゾーンの熱負荷と みなした。

図 9 に熱負荷計算結果を示す。両者の最大冷房負荷は 9 月 11 日 の 12 時に発生しており、全域空調方式採用時には、 $21.9 \mathrm{~kW}$ (この うち顕熱は $20.1 \mathrm{~kW}$ )、床吹き出し採用時には $21.1 \mathrm{~kW}$ (このうち顕 熱は居住域が $13.9 \mathrm{~kW}$ 、非居住域が約 $5.4 \mathrm{~kW}$ ) となった。これをも

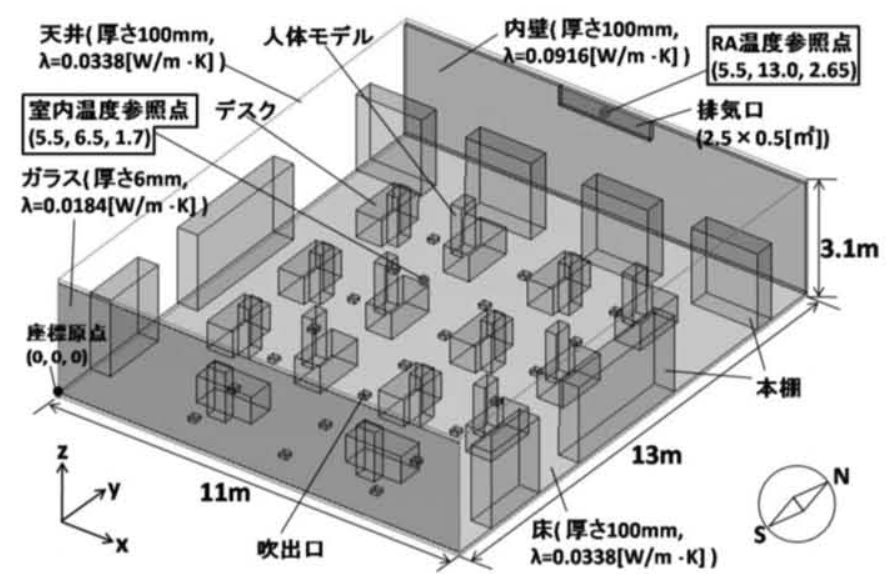

図 $7 \mathrm{CFD}$ の居室モデル (S3 ゾーンのみ)

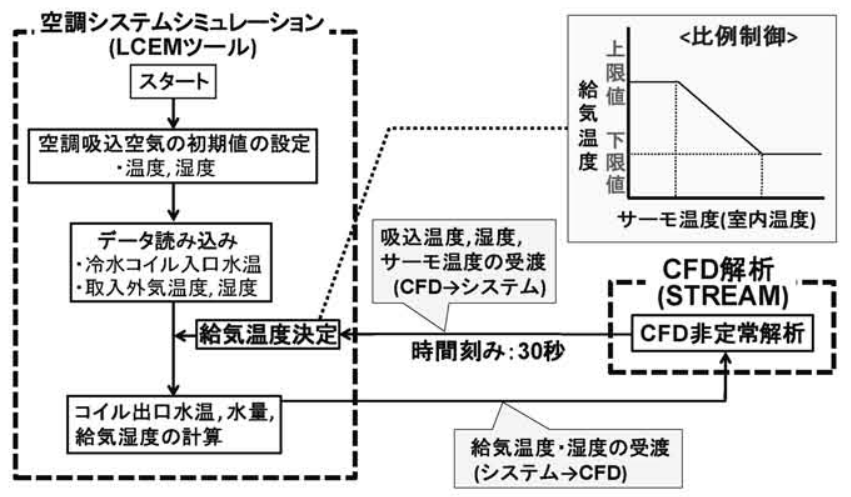

図 $8 \mathrm{CFD}$ 連成計算フロー

表 3 CFD 解析条件

\begin{tabular}{|c|c|}
\hline メッシュ数 & $86(\mathrm{x}) \times 102(\mathrm{y}) \times 24(\mathrm{z})=210,528$ \\
\hline \begin{tabular}{|l} 
移流項の \\
差分スキーム
\end{tabular} & 全ての保存則で QUICK を使用 \\
\hline 乱流モデル & 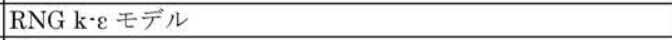 \\
\hline 流入境界 & \begin{tabular}{|l} 
速度 : $0.91[\mathrm{~m} / \mathrm{s}]$ \\
温度 : LCEM ツールの \\
計算値を用いる $\left(14 \sim 22^{\circ} \mathrm{C}\right)$ \\
湿度 : LCEM ツールの \\
$\quad$ 計算值を用いる $(\sim 90 \%)$ \\
$\quad$ 乱流エネルギー: $0.0069 \mathrm{~m}^{2} / \mathrm{s}^{2}$ \\
$\quad$ 散逸率 : $0.0018 \mathrm{~m}^{2} / \mathrm{s}^{3}$
\end{tabular} \\
\hline 流出境界 & 速度、温度、湿度全てに対して勾配 0 \\
\hline 壁面境界 & $\begin{array}{l}\text { 1) 速度 } \\
\text { 居室の東西面 : 対称境界 } \\
\text { それ以外の壁面(物体面含む) : 対数則 } \\
\text { 2) 床下面 : 断熱 } \\
\text { 3) 空面, 床面, 内壁面, 天井面 : ルイス則に基づく湿度伝達 } \\
\text { それ以外の面(物体面含む)：断湿 }\end{array}$ \\
\hline 発熱体 & $\begin{array}{c}\text { 照明 : } 20\left[\mathrm{~W} / \mathrm{m}^{2}\right] \\
\text { (天井・床に } 5 \text { 割ずつ体積発熱として与える) } \\
\mathrm{OA}: 20\left[\mathrm{~W} / \mathrm{m}^{2}\right] \fallingdotseq 204.3 \mathrm{~W} / \text { 台 } \\
(14 \text { 台のデスク上面に与える }) \\
\text { 人体(顕熱) }: 55[\mathrm{~W} / \text { 人 }] \\
\text { (人体モデル表面に与える) } \\
\text { 人体(潜熱) }: 63[\mathrm{~W} / \text { 人 }] \quad(\text { 人体モデル上面に水分発生量 } \\
\text { として与える }(0.025[\mathrm{~g} / \mathrm{s}]))\end{array}$ \\
\hline
\end{tabular}

とに、各ケースの空調機冷水コイルと送風機を決定した。表 4 に各 ケースの空調機仕様を示寸。各ケースの空調吹き出し温度は、ケー

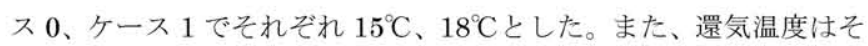
れぞれ $26^{\circ} \mathrm{C} 、 29.1^{\circ} \mathrm{C}$ とた。ここで、ケース 1 の還気温度は熱負荷 
計算時に得られた非居住域の室温を用いた。ケース 2 の空調機仕様 はケース 1 と同様に設定した。

\subsection{SysSimの計算条件}

表 5 に各ケースにおける SysSim の境界与条件を示す。ケース 0 とケース 1 は上述した負荷計算結果を与える。ケース 2 については、 CFD 側から空調吸い込み空気と室内温度参照点の温度を参照して 与える。シミュレーション期間は、最大負荷日の 9 月 11 日と部分 負荷日 4 月 12 日（日積算負荷出現頻度が冷房期間中 $10 \%$ 未満とな った日）の 8:00〜17:59 までとした。

\section{4. ケーススタディー結果・コイル処理熱量比較}

図 10 に最大負荷日（9 月 11 日）と部分負荷日（4月 12 日）にお ける各ケースのコイル処理熱量比較を示す。また、室内除去熱量と 外気負荷で分けて示寸。外気負荷は導入外気と室内還気のエンタル ピー差と風量から算定した。なお、外気負荷がマイナスの值を示す のは外気冷房されていることを意味する。

最大負荷日の日積算のコイル処理熱量はケース $0,1,2$ それぞれ $227.2 \mathrm{kWh} 、 203.8 \mathrm{kWh} 、 197.3 \mathrm{kWh}$ となり、全域空調を行うケース 0 がもっとも処理熱量が大きい（図 10(a)参照)。また、居住域空調 を採用するケース 1 はケース 0 に比べて約 $10.3 \%$ 小さく、非居住域 の温度上昇を許容したことで処理熱量を小さくできた。ケース 2 は 処理熱量が最も小さくなり、ケース 1 に比べて約 $13.2 \%$ 小さい。

次にケース間の外気負荷と室内除去熱量を比較する。ケース 0 と ケース 1 において、室内除去熱量は同じ值となったが、外気負荷は ケース 1 のほうが小さくなった。これはケース 1 の給気温度が高い ことが要因であると考えられる。

ケース 1 とケース 2 において、室内除去熱量はケース 2 のほうが 小さくなり、外気負荷熱量はほぼ同じであった。日積算の室内除去 熱量はケース 1 とケース 2 、それぞれ $165.0 \mathrm{kWh} 、 153.5 \mathrm{kWh}$ とな り、ケース 2 がケース 1 に比べて $6.9 \%$ 小さくなった。

図 11 に居室内温度分布図（9月11日、12 時のみ）を示す。床吹 き出し口から床上約 $1.0 \mathrm{~m}$ までは吹き出し空気の影響で低温域が見 られる。一方、OA 機器や人体からの発熱によって高温となった空気 が上昇し、室上部が高温となった。これによって部屋内には温度成 層を形成している。このように居室内の温度分布は、ケース 0,1 と で仮定している瞬時一様拡散の環境とは大きく異なっており、居室 内からの除去熱量がケース間で異なる要因となっていると考えられ る。

図 12 に各ケースの部屋中央の垂直温度分布を示す。なお、9 月 11 日の 12 時、 4 月 12 日の 12 時の結果をそれぞれ合わせて示す。 ケース 0 に対してケース 2 は上下に温度差ができており、この上下 の差はケース 1 に比べて大きいことが分かる。

表 6 に 9/11 における各ケースの室内温・湿度比較を示す。ケース 1 は居住域（FL $+1.7 \mathrm{~m}$ 以下）の温・湿度、ケース 2 は室内温度参照 点における温・湿度を示す。また、表 7 には各ケースの給気温度 ・ 還気温度の比較を示す。

各ケース間の室内温度は、ケース 2 の 8 時を除いて概ね $26^{\circ} \mathrm{C}$ に保 たれている。設定温度の $26^{\circ} \mathrm{C}$ に達成できてないことは比例制御のオ フセットが原因と考えられる。ケース $0 、$ ケース 1 は理想的に制御

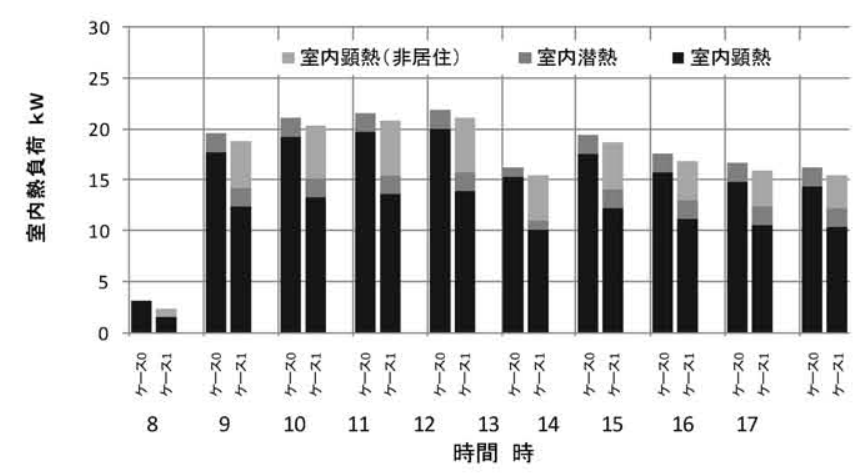

図 9 ケース 0,ケース 1 の熱負荷計算結果（9 月 11 日）

表 4 空調機の仕様

\begin{tabular}{|l|l|}
\hline ケース 0 & ケース 1,2 \\
\hline & アンダフロア型 \\
冷却能力: $32.0 \mathrm{~kW}$ & 冷却能力: $30.7 \mathrm{~kW}$ \\
正面面積: $0.532 \mathrm{~m}^{2}$ & 正面面積 $: 0.532 \mathrm{~m}^{2}$ \\
チューブ数: 20 本 $/$ 列 & チューブ数 $: 20$ 本 $/$ 列 \\
列数: 5 列 $(\mathrm{HF})$ & 列数 : 4 列 $(\mathrm{HF})$ \\
送風量 $: 5,600 \mathrm{~m}^{3} / \mathrm{h}$ & 送風量 $: 5,600 \mathrm{~m}^{3} / \mathrm{h}$ \\
外気導入量: $715 \mathrm{~m}^{3} / \mathrm{h}$ & 外気導入量 $: 715 \mathrm{~m}^{3} / \mathrm{h}$ \\
冷水水量 $93.1 \mathrm{lit} / \mathrm{min}$ & 冷水水量 $88.0 \mathrm{lit} / \mathrm{min}$ \\
冷水温度: $7 \cdot 12^{\circ} \mathrm{C}$ & 冷水温度 $: 7 \cdot 12^{\circ} \mathrm{C}$ \\
動力 $: 0.95 \mathrm{~kW}$ & 動力: $: 0.95 \mathrm{~kW}$ \\
\hline
\end{tabular}

表 5 各ケースのSysSim 境界条件

\begin{tabular}{|c|c|}
\hline ケース & 境界条件 \\
\hline ケース 0 & $\begin{array}{l}\text { 外気温度・湿度 } \\
\text { 室内負荷 }(\text { 顕熱・潜熱) }\end{array}$ \\
\hline ケース 1 & $\begin{array}{l}\text { 外気温度・湿度 } \\
\text { 居住域室内負荷（顕熱・潜熱） } \\
\text { 非居住気温度"1 }\end{array}$ \\
\hline ケース 2 & $\begin{array}{l}\text { 外気温度・湿度 } \\
\text { 吸い込み温度・湿度 } \\
\text { 室内サーモ温度”2 }\end{array}$ \\
\hline
\end{tabular}

されていてオフセットは生じない計算となっている。これに対して ケース 2 は CFD によりオフセットを再現していてこれがコイル処 理熱量に反映されているといえる。ケース 2 の 8 時に室温が $23^{\circ} \mathrm{C}$ と 低くなった原因は、給気温度の上限值を $22^{\circ} \mathrm{C}$ とたためである。湿 度はケース 0 が日中平均で $52.8 \%$ 、ケース 1 が $61.6 \%$ 、ケース 0 が $63.8 \%$ となり、給気温度の高いケース 1 とケース 2 の室内湿度がケ ース 0 に比べて高くなった。

以上より、コイル処理熱量はケース 0 、ケース 1 、ケース 2 の順 に小さくなることがわかった。また、ケース間の除去熱量の違いは、 居室内の垂直温度分布の性状、そして給気温度の違いによる潜熱処 理熱量が異なることが要因として考えられる。

ここからは、部分負荷日（4月 12 日）について、ケース間の比較 検討を行う。各ケースの日積算処理熱量は (図 10(b)参照)、ケース 0、ケース 1 、ケース 2 それぞれ $75.2 \mathrm{kWh} 、 64.1 \mathrm{kWh} 、 85.2 \mathrm{kWh}$ と なり、各ケース間の大小関係は最大負荷日と異なることがわかる。 


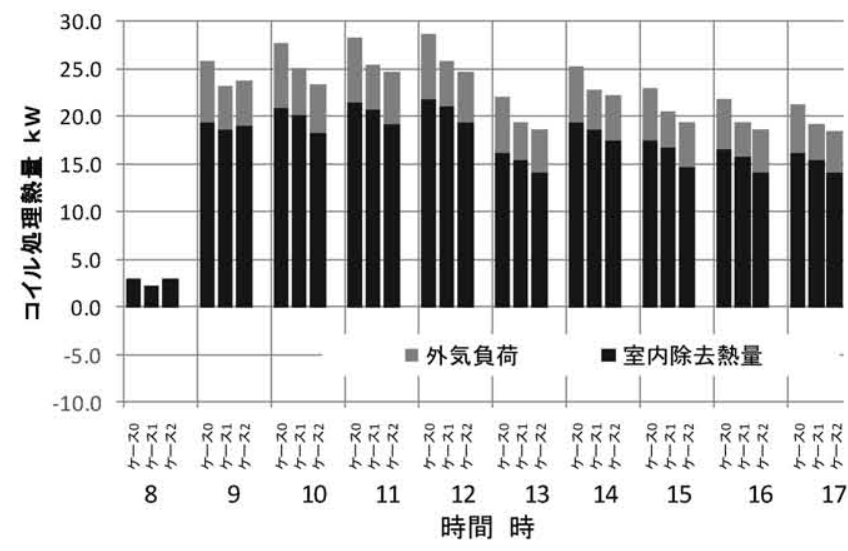

(a) 9 月 11 日

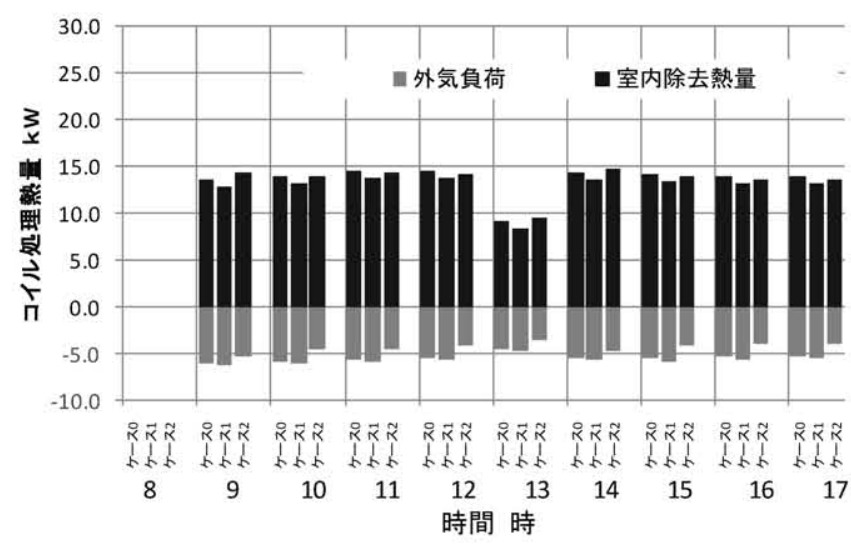

(b) 4 月 12 日

図 10 コイル処理熱量比較

温度 $\left[{ }^{\circ} \mathrm{C}\right]$

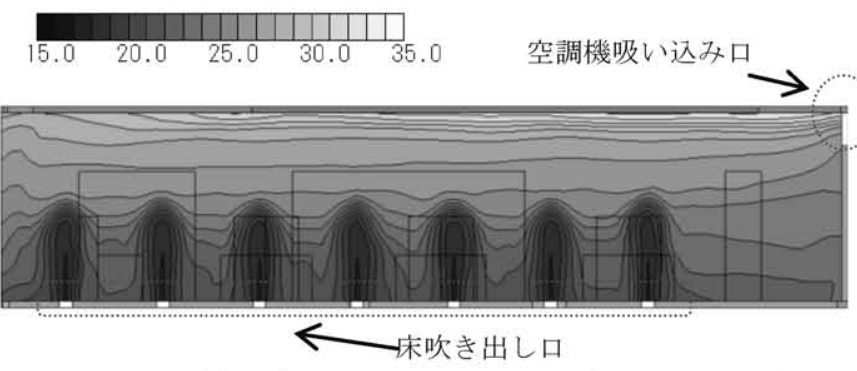

図 11 居室内温度分布図（9 月 11 日 12 時、 $x=5.5 \mathrm{~m}$ 断面）

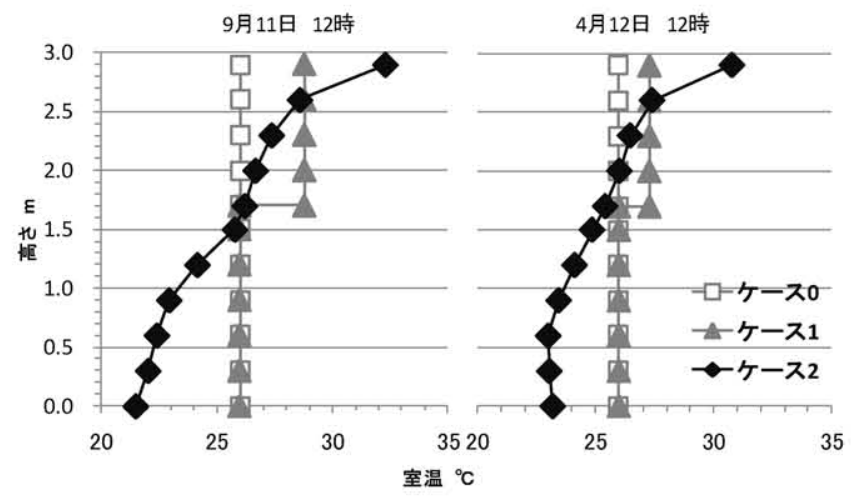

図 12 居室内垂直温度分布 (左 : 9 月 11 日、右 : 4 月 12 日)
表 6 各ケースの室内温度・湿度比較 $(9$ 月 11 日)

\begin{tabular}{|c|c|c|c|c|c|c|}
\hline & \multicolumn{2}{|c|}{ ケース 0} & \multicolumn{2}{c|}{ ケース 1} & \multicolumn{2}{c|}{ ケース 2} \\
\hline 時間 & 温度 & 湿度 & 温度 & 湿度 & 温度 & 湿度 \\
\hline 8:00 8:59 & 26.0 & 45.6 & 26.0 & 45.6 & 23.0 & 84.9 \\
\hline 9:00 9:59 & 26.0 & 52.6 & 26.0 & 62.5 & 25.8 & 59.8 \\
\hline 10:00 10:59 & 26.0 & 50.1 & 26.0 & 60.7 & 25.5 & 60.4 \\
\hline 11:00 11:59 & 26.0 & 49.4 & 26.0 & 60.2 & 25.9 & 57.5 \\
\hline 12:00 12:59 & 26.0 & 48.8 & 26.0 & 59.7 & 26.2 & 56.6 \\
\hline 13:00 13:59 & 26.0 & 56.1 & 26.0 & 66.3 & 25.6 & 65.0 \\
\hline 14:00 14:59 & 26.0 & 53.0 & 26.0 & 62.7 & 25.6 & 61.2 \\
\hline 15:00 15:59 & 26.0 & 56.2 & 26.0 & 65.0 & 25.4 & 63.4 \\
\hline 16:00 16:59 & 26.0 & 57.8 & 26.0 & 66.2 & 25.1 & 64.8 \\
\hline 17:00 17:59 & 26.0 & 58.6 & 26.0 & 66.7 & 25.1 & 64.9 \\
\hline
\end{tabular}

※各ケースのサーモ位置での温度・湿度を表す。ケース 0,1 については、居 住域の温度・湿度でもある。

表 7 各ケースの給気温度・還気温度比較 (9 月 11 日)

\begin{tabular}{|c|c|c|c|c|c|c|}
\hline \multirow{2}{*}{ 時 } & \multicolumn{3}{|c|}{ 給気温度 } & \multicolumn{3}{c|}{ 還気温度 } \\
\cline { 2 - 7 } & \multicolumn{1}{|c}{ ケース } & ケース 1 & ケース 2 & ケース0 & ケース 1 & ケース 2 \\
\hline 8:00 8:59 & 24.8 & 25.2 & 22.0 & 26.0 & 26.4 & 24.8 \\
\hline 9:00 9:59 & 17.1 & 19.5 & 18.5 & 26.0 & 28.4 & 27.4 \\
\hline 10:00 10:59 & 16.3 & 19.0 & 19.0 & 26.0 & 28.7 & 28.3 \\
\hline 11:00 11:59 & 16.1 & 18.9 & 18.3 & 26.0 & 28.8 & 28.0 \\
\hline 12:00 12:59 & 15.9 & 18.8 & 17.7 & 26.0 & 28.9 & 28.1 \\
\hline 13:00 13:59 & 18.4 & 20.7 & 18.8 & 26.0 & 28.3 & 27.3 \\
\hline 14:00 14:59 & 17.2 & 19.6 & 18.8 & 26.0 & 28.4 & 27.3 \\
\hline 15:00 15:59 & 18.2 & 20.2 & 19.3 & 26.0 & 28.0 & 26.8 \\
\hline $16: 00 \sim 16: 59$ & 18.7 & 20.5 & 19.8 & 26.0 & 27.8 & 26.4 \\
\hline $17: 00 \sim 17: 59$ & 18.9 & 20.6 & 19.8 & 26.0 & 27.7 & 25.5 \\
\hline
\end{tabular}

表 8 各ケースの室内温度・湿度比較 (4月 12 日)

\begin{tabular}{|c|c|c|c|c|c|c|}
\hline & \multicolumn{2}{|c|}{ ケース0 } & \multicolumn{2}{c|}{ ケース 1} & \multicolumn{2}{c|}{ ケース 2} \\
\hline 時間 & 温度 & 湿度 & 温度 & 湿度 & 温度 & 湿度 \\
\hline 8:00 8:59 & 26.0 & 50.0 & 26.0 & 50.0 & 22.4 & 83.2 \\
\hline 9:00 9:59 & 26.0 & 46.1 & 26.0 & 46.1 & 25.2 & 66.0 \\
\hline 10:00 10:59 & 26.0 & 47.7 & 26.0 & 47.7 & 25.1 & 65.6 \\
\hline 11:00 11:59 & 26.0 & 49.1 & 26.0 & 49.1 & 25.2 & 65.1 \\
\hline 12:00 12:59 & 26.0 & 50.0 & 26.0 & 50.0 & 25.4 & 64.1 \\
\hline 13:00 13:59 & 26.0 & 43.5 & 26.0 & 43.5 & 24.5 & 72.6 \\
\hline 14:00 14:59 & 26.0 & 50.9 & 26.0 & 50.9 & 25.3 & 64.9 \\
\hline 15:00 15:59 & 26.0 & 50.9 & 26.0 & 50.9 & 25.2 & 65.2 \\
\hline 16:00 16:59 & 26.0 & 50.0 & 26.0 & 50.0 & 25.2 & 65.7 \\
\hline 17:00 17:59 & 26.0 & 49.1 & 26.0 & 49.1 & 25.4 & 65.0 \\
\hline ※各ケースのサーモ位置での温度・湿度を表す。ケース 0,1 ケつては、居 \\
住域の温度・湿度でもある。
\end{tabular}

これはケース 2 の室温がほかのケースに比べて低くなったことが 原因であると考えられる。表 8 に示す室内温度の結果と、図 12 (右) に示す 12 時の垂直温度分布から、ケース 2 の室温がほかのケース 
より低いことが確認できる。これにより、コイルでの外気負荷が減 る一方で室内除去熱量は増えており、ケース 1 とケース 0 に比べて、 コイルの処理熱量は大きくなった。

このことから、部分負荷日においてコイル処理熱量は室負荷の低 減に伴い減少する。しかし、完全混合と仮定したケース（ケース0 とケース 1）に比べて、その減少度合いは実際（ケース 2）では小 さくなる可能性があることが示されたといえる。

図 13 に 9 月 11 日の冷水流量と出口水温経時変化の比較を示す。 各ケース間でコイルにかかる冷却負荷が異なることは、前節で確認 できた。これに加えて、還気の気温と湿度が異なることで、コイル 入口への空気温度と湿度が異なってくる。このため、冷水流量と冷 水還り水温が各ケース間で異なっていることがわかる。日積算の冷 水流量は、ケース 0、ケース 1、ケース 2 それぞれ 24,780 に、 19,920

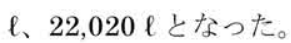

このようなシステム挙動は、冷水ポンプの動力と熱源運転効率に 影響するものであり、CFD を活用することによってより実状に近い 状態のシステム挙動を再現しているといえる。

\section{5. 熱源システム設計とエネルギー消費量評価}

前章では、各ケース間のコイル処理熱量の相違とこれの影響を受 けるシステム挙動の違いについて検討し、その要因について考察し た。ここでは、冷房期間中（4月～10月）におけるケース 0 のコイ ル処理熱量をベースにケース 1 、ケース 2 の装置負荷プロフィール を作成した。コイル処理熱量を適宜倍数して装置負荷と見なした注2。 また、これらの装置負荷をもとに熱源システムを設計し、SysSim を行った。

\section{1 ケース 1、ケース 2 の装置負荷作成}

ケース 1 とケース 2 の装置負荷は、 4 月 12 日、9 月 11 日の 2 日 間のみ既知であり、ケース 0 と各ケースの同じ時間帯の装置負荷と の相関関倸から泠房期間全体の負荷を作成した。ケース 0 とケース 1、ケース 0 とケース 2 のそれぞれの R2 係数は 0.99、0.98 と高い 相関を示したため、今回作成したケース 1 、ケース 2 の冷房期間中 の除去熱量は概ね妥当なものと考えられる。

図 14 に各ケースの期間積算の装置負荷を示寸。ケース 0 の期間 積算の装置負荷は $726 \mathrm{MWh}$ であり、ケース 1 が $647 \mathrm{MWh、ケース}$ 2 が $668 \mathrm{MWh}$ となった。図 15 に建物全体の装置負荷のデュレーシ ヨンカーブを示寸。ケース 0 の装置負荷のデュレーションカーブに 対して、ケース 1 のカーブは約 1300 時間の間は小さく、それ以後 はほぼ一致している。ケース 2 のカーブは約 1300 時間を堺にカー ブが逆転しており、100kW 以下の低負荷が見られない。

各ケースの装置負荷の最大值は、それぞれ $801 \mathrm{~kW} 、 725 \mathrm{~kW} 、$ $692 \mathrm{~kW}$ となった。

\section{2 設計条件}

前節にて作成した装置負荷の各ケース最大值をもとに熱源システ ムの設計を行った。採用する熱源機器は空気熱源ヒートポンプュニ ットとし、LCEM ッール内の汎用機器シリーズの中から熱源構成を 選定した。また、冷水一次ポンプと二次ポンプについても選定を行 った。

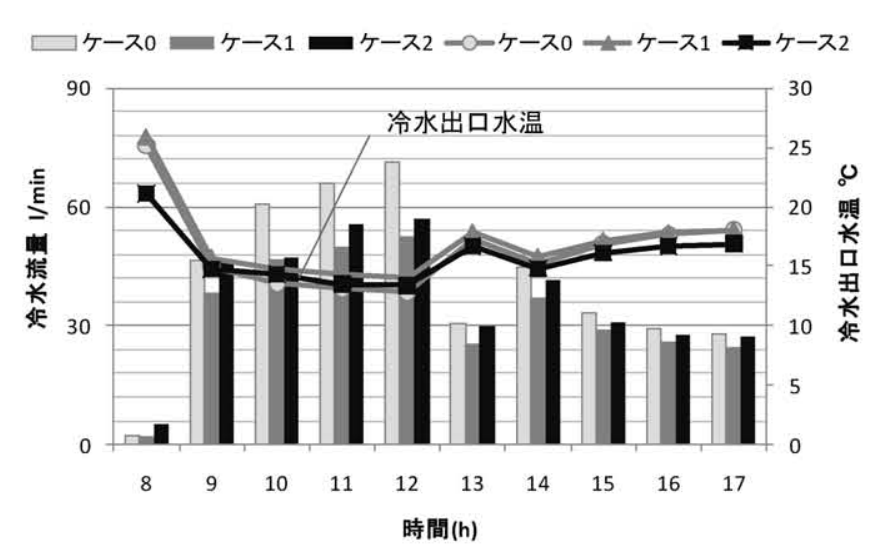

図 13 冷水流量と出口水温経時変化比較（9 月 11 日）

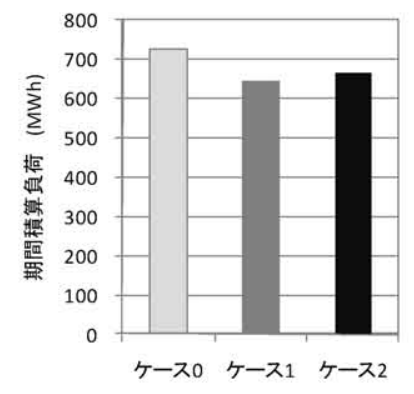

図 14 期間積算装置負荷

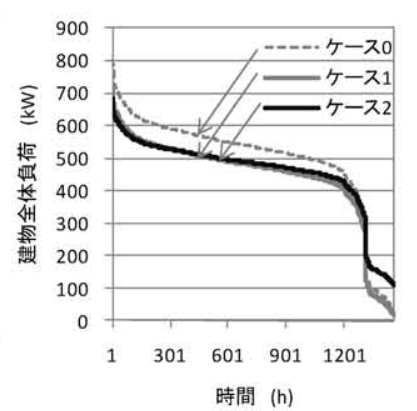

図 15 建物全体の装置負荷の デュレーションカーブ

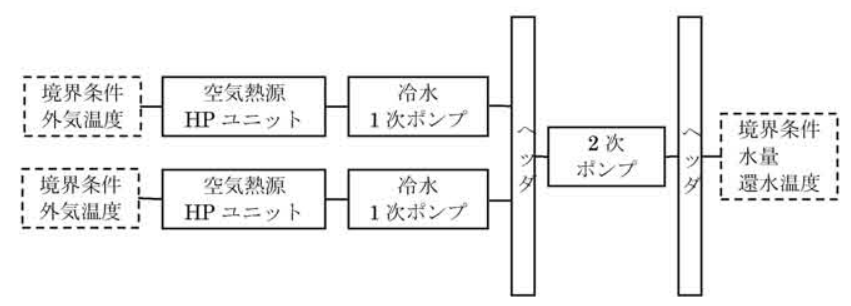

図 16 システムシミュレーションに用いたモデル

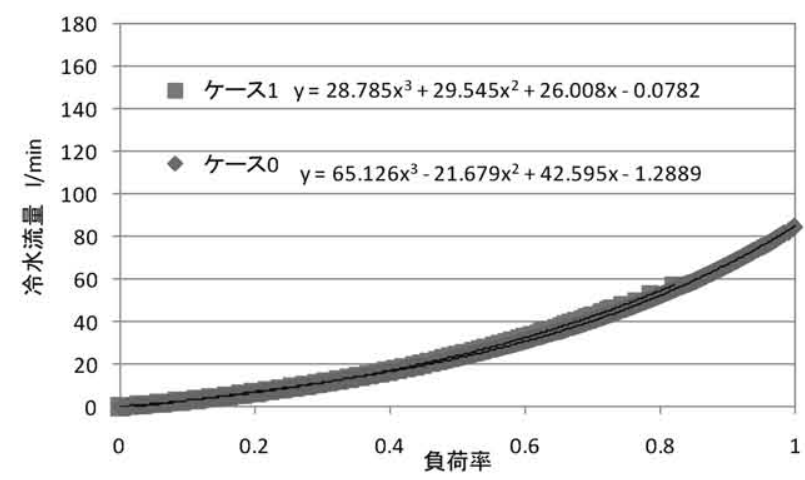

図 17 検討に用いたコイルオブジェクト特性 （負荷率と冷水流量との関係）

表 9 に各ケースについて選定した熱源機器の構成を示す。図 16 にSysSimに用いた LCEMツールの構築モデルダイアグラムを示す。 シミュレーション範囲は、熱源機器から泠水二次ポンプを含む熱源 
サブシステムとした。また、シミュレーションの境界条件には、外 気条件と装置負荷を与えた。装置負荷は、図 17 に示寸近似曲線を 用いて二次側冷水流量と還水温度に読み替えて与えた。これにより 冷水コイルの特性を考慮できるようにした。熱源運転は、台数制御 ののち並列絞り運転とし、送水温度は $7^{\circ} \mathrm{C}$ 、泠水一次ポンプは定流 量制御 $(\mathrm{CWV}) 、 二$ 二次ポンプは変流量制御（VWV）とした。

\section{3 計算結果の比較と考察}

図 18 に期間積算エネルギー消費量と期間熱源システムCOPを示 す。HS0、HS1、HS2 のケース（ケース名は表 9 参照）のエネルギ 一消費量はそれぞれ $173 \mathrm{MWh} 、 163 \mathrm{MWh} 、 166 \mathrm{MWh}$ となった。居 住空間全域に対して完全混合と仮定したケース（HS0）のエネルギ 一消費量が最も大きくなり、HS2、HS1の順の大きさとなった。各 ケースのエネルギー消費量は、HS0 を基準に HS1 は 5.7\%、HS2 は $4.1 \%$ 小さくなる結果となった。

熱源サブシステムの COP は、HS0、HS1、HS2 それぞれ 4.19、 3.97、4.03 となった。また、熱源単体の COP は 4.84、4.55、4.60 となった。ケース間のシステム COP の大小関係は、表 9 に示寸熱 源機器の定格 COP の大小関係と同様となり、今回の検討では負荷 パターンの違いによる影響は見られなかった。

表 9 熱源構成ケース

\begin{tabular}{|c|c|l|c|}
\hline $\begin{array}{c}\text { 熱 源 構成 } \\
\text { ケース名 }\end{array}$ & $\begin{array}{c}\text { ピーク負荷 } \\
\mathrm{kW}\end{array}$ & $\begin{array}{l}\text { 機器能力 } \mathrm{kW}(\text { 定格 } \\
\mathrm{COP}) \times \text { 台数 }\end{array}$ & 負荷率* \\
\hline HS0 & $801($ ケ-ス 0) & $425 \mathrm{~kW}(3.65) \times 2$ 台 & 0.92 \\
\hline HS1 & $725($ ケ-ス 1$)$ & $375 \mathrm{~kW}(3.44) \times 2$ 台 & 0.97 \\
\hline HS2 & $692($ ケ-ス 2$)$ & $375 \mathrm{~kW}(3.44) \times 2$ 台 & 0.94 \\
\hline
\end{tabular}

*機器能力に対する最大負荷の割合

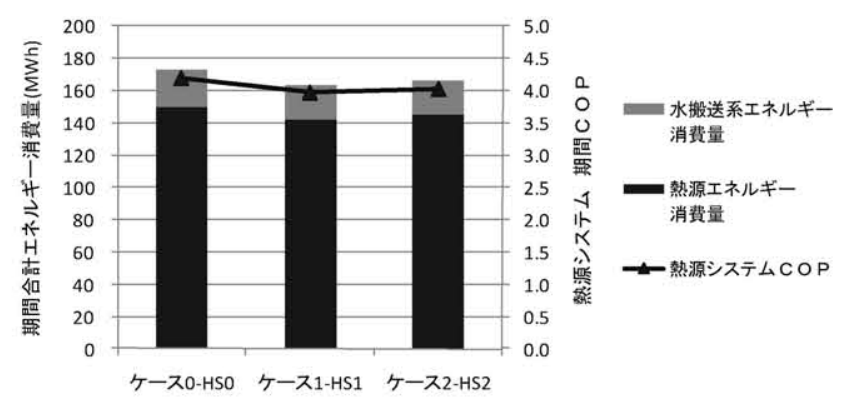

図 18 期間積算エネルギー消費量と期間システム COP

\section{6. まとめ}

SysSim と CFD 連成計算の意義とその適用可能性を示すため、床 吹き出し空調方式を採用する建物を想定し、CFD を連成した SysSim を行った。今回は設計段階での有効性を検討し、CFD 連成 有無の違いによる装置負荷の相違を比較検討した。

空調システムの装置負荷は CFD との連成計算有無によって異な ってくることを確認した。また、空調機の給気温度設定、室内温度 分布がその主たる要因であり、CFD との連成計算によってその影響 が明らかになった。CFD と連成することによって生じる空調装置負 荷の違いは、全体的に装置負荷は小さくなるとともに、低負荷時の 負荷率が上がる傾向を示す。空調熱源機器の装置容量選定時に適切
な装置負荷予測を可能にし、実負荷に見合う機器容量の選定時に有 効といえる。

今後、CFD と連成する $\operatorname{SysSim}$ の信頼性検証を行うとともに、施 工・運転段階での適用可能について検討寸る予定である。

\section{参考文献}

1) J.C. Lam, A.L.S. Chan : CFD analysis and energy simulation of a gymnasium, Building and Environment, 36., pp.351 358, 2001

2) Z. Zhai, Q. Chen : Performance of coupled building energy and CFD simulations, Energy and Buildings, 37., pp.333 344, 2005

3) Z. Zhai, Q. Chen : Solution characters of iterative coupling between energy simulation and CFD programs, Energy and Buildings, 35., pp.493 505, 2003

4) Z. Zhai, Q. Chen : Sensitivity analysis and application guides for integrated building energy and CFD simulation/ Energy and Buildings, 38., pp.1060 1068, 2006

5）鄭ほか：床下空間を空調還気経路とした大規模体育館の温熱環境（その 3 ) 空調制御と非定常 CFD の連成解析による検討, 日本建築学会大会学術 講演梗概集, D·2, 環境工学 II, pp.1399 1400, 2006

6) 飯田ほか：事務所ビルの空調システムの制御と診断に関する研究, (第 3 報) CFD と HVACSIM+(J) との連成解析による検討, 空気調和・衛生工学 会大会学術講演会論文集, pp.2187 2190, 2008

7) 岡崎徳臣,奥宫正哉ほか: ライフサイクルエネルギーマネジメントのため の空調システムシミュレーション開発(第 3 報),(第 7 報), 空気調和・衛生工 学会学術講演会論文集, 2006

8）空気調和 - 衛生工学会編集部, 空気調和 - 衛生工学便覧第 14 版, 空気調 和・衛生工学会, Vol.1, p.397, 2010

9) Y. Tominaga, T. Stathopoulos : Numerical simulation of dispersion around an isolated cubic building : Comparison of various types of $\mathrm{k} \cdot \mathrm{e}$ models, Atmospheric Environment, 43 pp.3200 3210, 2009

10) H. Sun, L. Zhao, Y. Zhang : Evaluating RNG k-e models using PIV data for airflow in animal buildings at different ventilation rates, Transactions of ASHRAE, 113(1), pp.358 365, 2007

注

注 1) 居室の上下温度分布を上下二層（各層は均一温度）に分割して考慮し、 負荷計算を行う。床上 $1.7 \mathrm{~m}$ までを居住域、それ以上を非居住域とし、 居住域の空気は非居住域に押し出されるピストンフローと仮定した。ま た、内部発熱については、人体発熱は居住域に全量を与え、照明発熱は 居住域と非居住域に半分ずっ与えた。先ず、居住域の設定温度を $26^{\circ} \mathrm{C}$ と し、負荷を算出した。そして、床吹きの給気温度を $18^{\circ} \mathrm{C}$ と仮定し、給気 風量を算出した。この給気風量が非居住域一流入することで与えられる 熱量と非居住域の熱負荷が釣り合うときの非居住域の温度を算定した。 非居住域温度は空調機の還気温度として使われる。

注 2)簡便のため、ソーン間、階ごとの負荷偏差は無視した。図 4 の”S3"、"S4" ゾーンの装置負荷を 4 倍して 1 フロアの装置負荷を算定し、さらに 9 倍 して 9 階建ての想定建物全体の装置負荷とした。

(2010年 3 月 10 日原稿受理, 2010 年 9 月 7 日採用決定） 